\title{
VALUATION OF INTERNET STOCKS - AN IPO PERSPECTIVE
}

\author{
Eli Bartov \\ Leonard N. Stern School of Business \\ New York University \\ ebartov@ stern.nyu.edu \\ Partha Mohanram \\ Leonard N. Stern School of Business \\ New York University \\ pmohanra@stern.nyu.edu
}

\author{
Chandrakanth Seethamraju \\ Olin School of Business \\ Washington University \\ seethamraju@olin.wustl.edu
}

April 2001

Accepted to the 2001 Journal of Accounting Research Conference. 


\section{Valuation of Internet Stocks - An IPO Perspective}

\section{Introduction}

Since its onset in 1994, the Internet industry has exhibited unprecedented growth in the number of firms and market capitalization. In 1994, two Internet companies went public, raising less than 65 million dollars; in 1999, 192 Internet firms went public, raising over 14 billion dollars. The importance of this industry to the investment community, assertions that traditional valuation methods do not apply to Internet companies, and the difficulties in valuing high-tech companies have led academics to search for value drivers of Internet companies. 1

Hand (2000a) was the first to show that financial statement data--core net income (defined as net income less special items) and pre-income book values--are value-relevant during the period 1997 to mid-1999. Specifically, he finds that the market values of Internet firms are linear and increasing in their book equity and concave and increasing in positive core net income, but concave and decreasing in negative core net income. This last (counterintuitive) result, which implies the larger the loss the greater the stock price, is ascribed to investors' ability to unravel the accounting conservatism reflected in expensing rather than capitalizing marketing and $\mathrm{R} \& \mathrm{D}$ expenditures. Hand also documents concavity in the pricing of marketing and $R \& D$ expenditures, a finding he considers puzzling because the common wisdom of economy to scale of such investments for Internet companies would predict convexity. Unlike Hand (2000a), Trueman et al. (2000) find a significant negative, not positive, association between earnings and Internet firms' market prices. After

\footnotetext{
${ }^{1}$ The claims that traditional valuation methods do not apply to Internet companies are based on the argument that these companies represent the New Economy, in which new valuation rules apply. For example, in contrast to the traditional bricks-and-mortar companies of the Old Economy, the virtual companies of the New Economy invest primarily in intangible assets and hold little inventory.
} 
decomposing earnings into its components, however, they find gross profits to be significantly positively associated with prices. Demers and Lev (2000) and Hand (2000b), among others, investigate the valuation relevance of Web traffic for Internet companies. They generally find that some measures of Web traffic, particularly those indicating "reach" (percentage of a Web site's visitors relative to the total Web-surfing population), are value-relevant, but the book value of equity and current and expected future earnings dominate the Web traffic measures in explaining Internet companies' market values.

The purpose of the current study is to shed light on the valuation of Internet firms at the time of their initial public stock offerings (IPOs). Given the large number of Internet IPOs since 1994 (over 400), the expected Internet IPOs in the future, the unique characteristics of this industry, and the substantial differences in the amount and type of information available for IPOs vis-à-vis publicly traded companies, the search for value drivers of Internet IPOs is important to entrepreneurs, underwriters, investors, and accountants. We examine the value drivers underlying Internet IPOs from two perspectives: the final offer price and the stock price at the end of the IPO's first trading day.

The underwriter (and the issuing firm) set the offer price. This price primarily reflects the underwriter's private information about the firm's future prospects and information he/she has gathered about the demand for the issue from (sophisticated) investors actively involved on an ongoing basis in purchasing shares of firms going public. The determinants of the final offer price should indicate the value drivers underlying Internet stocks perceived to be important by the most informed and sophisticated players in the capital market.

The IPO price at the end of its first trading day should indicate the way small investors price Internet stocks. Small investors typically have little access to IPOs, so their first opportunity to acquire shares of Internet firms occurs when the shares first trade on the 
exchange. We expect the price at the end of the first day of trading to differ substantially from the offer price even if both are rationally determined. This follows from the well-known fact that IPOs tend to be underpriced; i.e., they tend to trade significantly above their offer price in their debut (see, e.g., Ibbotson and Ritter 1995 for a review of the literature on IPO underpricing).

Our examination involves a matched-pair design in which a sample of Internet IPOs (the test sample) is matched on the IPO's date and value of offering with a sample of nonInternet IPOs (the control sample). Our first set of tests regresses, by sample, the offer price on four explanatory variables: the book value per share (BVPS), the annual sales growth (SGR), the percentage of shares outstanding offered in the IPO (FLOAT), and a performance measure. ${ }^{2}$ For the performance measure we use three alternative variables: sales per share (SALESPS), earnings per share, and operating cash flow per share. The last two variables are broken up into their positive and negative components due to evidence in prior research indicating a differential association between these two components and equity value.

For Internet firms, we find that FLOAT, SALESPS, SGR, and positive and negative operating cash flows are significantly related to the offer price in the predicted direction. FLOAT is expected to relate to the offer price because, in our sample period (1/96 - 6/99), underwriters had little experience in pricing Internet companies and only a limited amount of firm-specific information for the IPOs because of their short history and lack of profitability. The percentage of shares offered to the public, which may serve as a signal for the

\footnotetext{
${ }^{2}$ Unlike some of the prior research discussed above, we do not include measures of Web traffic (e.g., reach) in our analysis for two reasons. First, about half of our sample firms belong to sectors that are involved in Internetrelated activities that do not map into Web-site traffic, e.g., Performance Software, Internet Security, and Speed/Bandwidth (see the full list of Internet sectors in the next section). Second, we replicate the analysis using the subsample for which Web-traffic measures are available and find them to be insignificant. This finding is consistent with prior research (e.g., Hand 2000b) showing that book value and earnings dominate Web-traffic variables.
} 
unobservable information of the entrepreneurs about the future prospects of their company (see Leland and Pyle 1977), thus is an important value driver. Sales and sales growth are expected to relate to offer price because top line performance and growth assume importance in the absence of current bottom-line profits. The relation between the offer price and operating cash flows varies with their sign. While positive cash flows (POSCFO) are valued positively, negative cash flows (NEGCFO) are negatively related to the offer price, indicating that they are potentially viewed as investments.

For non-Internet firms, we find that FLOAT is related to the offer price, and that other than sales none of the financial variables explain the cross-sectional variation in the offer price. This is an unexpected result, as we expect factors such as earnings and cash flows to be value-relevant for traditional firms. A closer examination indicates, however, that earnings and sales growth were indeed significant for non-Internet firms in the period 1/96 -12/98, but lost their significance in the height of the technology boom (1/99 - 6/99), a period during which the market paid little attention to financials.

Our second set of tests investigates the association between the IPO price at the end of its first trading day and five explanatory variables; we augment the model above by adding one explanatory variable, PARTIAL. PARTIAL is defined as the final offer price scaled by the midpoint of the anticipated offer price's range disclosed in the preliminary prospectus. We add this variable because prior research has shown theoretically (see Benveniste and Spindt 1989) and empirically (see Hanley 1993) that this variable is an important predictor for IPOs' first-day stock price performance.

For the Internet firms, we find two financial variables to be significant: positive book

\footnotetext{
${ }^{3}$ This variable captures the partial adjustment of the offer price to new information gathered by the underwriter in the pre-issue period. This matter is further discussed below.
} 
value and sales growth, potentially because they indicate the IPO firms' long-term prospects. The two non-financial variables, FLOAT and PARTIAL, are also significant. Thus, in their debut, investors price Internet stocks on the basis of two financial variables providing direct information about the firms' prospects as well as two non-financial variables serving as signals for the unobservable (superior) information of the entrepreneurs (FLOAT) and underwriters (PARTIAL).

For non-Internet firms, we find only sales growth to be significant among the financial variables. Again, partitioning the sample into two subperiods, 1/96 - 12/98 and 1/99 - 6/99, indicates that earnings were highly significant prior to 1999 , but lost their significance as the market turned a blind eye toward financial-statement information in 1999. PARTIAL and FLOAT are both significant, but, as expected, their valuation effect is stronger for Internet firms than for non-Internet firms. This indicates that the information asymmetry between less informed (small) investors and more informed investors (underwriters and entrepreneurs) on the IPO debut is higher for Internet stocks.

The next section provides background on the Internet industry and the IPO process. Section 3 develops the hypotheses. Section 4 describes the sample selection procedure and reports summary statistics for and pair-wise correlation among all variables used in the analysis. Section 5 outlines the tests and discusses the results. Section 6 concludes the study with a summary of our findings.

\section{Background on the Internet Industry and the IPO Process}

\subsection{THE INTERNET INDUSTRY}

By March 2000, six years since its inception (and just before its meltdown), the Internet industry had become the second leading technology industry in terms of wealth 
creation with a total market value exceeding the $\$ 1$ trillion mark, trailing only slightly the more mature software industry. It consists of over 400 publicly traded companies in the U.S., which may be classified into the following 12 sectors: ${ }^{-1}$

1. Reach/Portals: Companies that run Web sites designed to be gateways to the Internet. Nearly all rely primarily on advertising revenue, feature news, and information organized by category; all offer Internet search capabilities.

2. Content/Communities: Companies that run Web sites and networks organized around specific content such as sports, politics, and stocks. Some are business-to-business (B2B) oriented; others are geared toward consumers or a mix.

3. E-Tailers: Companies that sell goods or services online to consumers, business, or both.

4. Financial Services: Online stockbrokers, loan processors, credit-card providers, banks, and venture-capital companies.

5. E-Commerce Enablers: Companies that provide software that enables B2B e-commerce.

6. Internet Security: Companies that sell firewalls and e-commerce security software (digital certificates) and provide outsourced services.

7. Performance Software: Companies that produce a wide range of software products for the Internet: operating systems (Red Hat), software that measures Web site performance, software that allows users to do something (use the Internet to make long-distance calls), and software that allows users to build applications.

8. Internet Services: Companies that offer services such as Web hosting, e-mail management, application hosting, and delivery and employment listings.

9. Advertising/Marketing: Ad services providers, direct marketing companies, and Web site traffic measurers.

\footnotetext{
${ }^{4}$ See http://www.wsrn.com/help/igroups_def
} 
10. Consultants/Designers: Companies that offer a variety of services including business development, Web design, software development, marketing, e-commerce services, etc. They are differentiated from E-Commerce Enablers by the breadth of their services.

11. Speed/Bandwidth: Companies that are trying to improve the performance of the Internet, including cable-access providers, caching server vendors, and router and switch makers.

12. ISPs/Access Providers: Companies that provide Internet access to computers, corporate clients, wireless devices, etc.

Valuing technology stocks is a formidable task due to their massive investments in intangible assets (e.g., R\&D) whose values are typically hard to ascertain. Valuing Internet stocks is even more difficult because they not only invest heavily in intangible assets (e.g., developing new technologies and a critical mass of clientele), they actually attempt to transform the way in which business is transacted. Although virtual Internet companies are expected to grow rapidly and dominate or perhaps even make irrelevant their traditional bricks-and-mortar competitors, the vast majority of Internet companies have yet to show a profit. This lack of profitability further contributes to the growing uncertainty and confusion that have surrounded the valuation of Internet stocks virtually since the inception of the industry. A case in point: BusinessWeek, in its December 14, 1998 issue, provides excerpts of an e-mail message from an apparently confused investor posted at Internet.com, "I have some Internet stocks...I'd sure like to buy more. But I'll think to myself, these stocks are ridiculously high, they CAN'T go higher. BUT THEY DO...I can't bear missing out on the excitement. But I also can't connect reality to what I see in the stock valuations.”

Still, not everyone seems confused by Internet companies' valuations. For example, by applying a real-options theory and capital-budgeting techniques, Schwartz and Moon (2000) demonstrate that the seemingly skyrocketing valuations of Internet companies may be 
rational if growth rates in revenues are sufficiently high and volatile.

\subsection{THE IPO PROCESS}

Going public (i.e., raising money by selling stocks to the public for the first time) typically marks the transformation from startup adolescence to corporate adulthood. A public company commands, among other things, instant credibility and a publicly traded stock that can be used as a currency to finance acquisitions. These benefits may explain why, in the tenyear period 1990-1999, more than 5,000 firms went public, raising nearly 400 billion dollars (see Table 2 below).

Once a company's board of directors has decided to go public, the company hires an investment banker to underwrite the offering. The company then drafts the prospectus, the only document a company can use to communicate with potential investors during an IPO. The prospectus contains, among other things, financial information about the company and the terms of the offer. In a firm commitment offer, the terms of the offer include the offer price, which is stated in the form of a range whose midpoint is the expected offer price. Upon completion, the prospectus is filed with the Securities and Exchange Commission (SEC).

The time from the filing of the prospectus to the final offer date is the "waiting period." During this period, the firm's top management (e.g., the CEO and CFO), accompanied by analysts of the underwriter, meets with investors in the so-called "roadshows." A roadshow may be one-on-one with a money manager or a meeting with 20 or more investors from different funds. These meetings begin with a presentation by the company's managers, in which they pitch to investors, to be followed by a Q\&A session.

The underwriter uses the waiting period to gather information about the demand for the issue from investors through nonbinding indications of interest. If demand for the issue is greater (lower) than expected, the final offer price will be set higher (lower) than the expected 
offer price disclosed in the prospectus. Obviously, to induce truth-telling by investors with good information in the waiting period, the expected profit of truth tellers must be higher than

that of the liars. If shares of the issue are rationed, this must be obtained by underpricing. Benveniste and Spindt (1989), who develop a model of pricing and allocation rules used by underwriters of IPOs to induce truth-telling by investors, predict that IPOs priced toward the upper bound of their offer range are likely to be more underpriced than other IPOs. The intuition underlying this prediction follows, because if the potential underpricing at the expected offer price is relatively large, a firm is able to increase its final offer price and still have more underpricing than other firms with less initial underpricing. Consistent with this prediction, Hanley (1993) documents a positive association between the stock price change of IPOs in their first trading day and the ratio of the final offer price to the expected offer price disclosed in the prospectus.

\section{Hypothesis Development}

This study examines value drivers underlying the IPO offer price (IPOPRICE) and the price at the end of the first trading day (ENDPRICE). These two prices are likely to reflect the views of very disparate capital market participants. The underwriter, along with the issuing company's managers, sets the offer price. Examining the determinants of the offer price should thus indicate the value drivers perceived to be important by the most informed and sophisticated players in the capital market.

The price at the end of its first trading day should indicate the way small investors price the stock. Small investors are hard-pressed to acquire shares in IPOs because the bulk of these shares are sold to the large clients of the investment banks and brokers. According to

\footnotetext{
${ }^{5}$ Changes in the offer price are often accompanied by parallel revisions in the number of shares being offered.
} 
The Wall Street Journal (1999), small investors typically get only 25 percent or less of the shares in a traditional IPO. ${ }^{6}$ For many small investors, the first opportunity to obtain shares of an IPO firm is thus when the shares trade on the exchange. As noted above, IPOs tend to be underpriced (see Ibbotson and Ritter 1995); the price at the end of the first day of trading therefore differs substantially from the offer price even if both are rationally determined.

Our tests evaluate the ability of five financial variables--earnings per share (EPS), operating cash flow per share (CFOPS), sales per share (SALESPS), book value per share (BVPS), and the annual sales growth (SGR)--to explain the cross-sectional variation in IPOPRICE and ENDPRICE. We select these five explanatory variables because prior research has shown that these variables are important for equity valuation in non-IPO contexts. Our tests also consider one non-financial variable, FLOAT, for IPOPRICE, and for ENDPRICE two non-financial variables, FLOAT and PARTIAL, because prior literature on the pricing of IPOs has demonstrated their importance in explaining the IPO offer price and day 1 end price, respectively. In the next section, we develop our hypotheses concerning the relation between our dependent and explanatory variables (summarized in Table 1).

\subsection{RELATION BETWEEN IPOPRICE AND ENDPRICE AND THE FINANCIAL VARIABLES}

\section{Earnings and Cash Flows}

In equity valuation, the most commonly used financial variables are earnings and cash flows. For example, earnings are used in the ubiquitous $\mathrm{P} / \mathrm{E}$ ratios (and more recently $\mathrm{P} / \mathrm{E}$ to growth ratios, i.e., PEG), and cash flows are used in methods of valuation such as the discounted cash flow (DCF) model. Prior research has shown asymmetries in the relations

\footnotetext{
${ }^{6}$ In contrast, in the 1999 Dutch auction IPO of Andover.net, in which both individual and institutional investors competed for shares on equal footing, about $50 \%$ of the four million shares sold went to individual investors (see The Wall Street Journal 1999).
} 
between market values of equity and positive and negative earnings (see, e.g., Hayn 1995, and Hand 2000). These asymmetries follow because positive earnings are likely to persist, while negative earnings are likely to be transitory and thus less informative about future earnings and cash flows. We hence break up our measures for earnings and cash flows into positive and negative components by interacting them with a dummy variable. We, however, expect positive earnings and cash flows to be positively associated with the dependent variables only for the non-Internet firms. For Internet firms, positive earnings and cash flows are likely to be contaminated by large write-offs of intangible assets.

Negative earnings and cash flows of non-Internet firms are not expected to relate to our dependent variables as they are likely to be transitory and thus provide little information about future earnings and cash flows. For Internet firms, however, negative earnings and cash flows may be viewed by the capital market as resulting from investments in intangible assets through activities such as research and development, advertising, and other market-building activities that are expensed under current generally accepted accounting principles (GAAP). If this is the case, we expect a negative correlation between our dependent variables and negative earnings and cash flows for Internet firms.

\section{Sales and Sales Growth}

In the absence of a history of profits and meaningful book values, conventional wisdom suggests that investors rely on revenue as an important financial value driver. Consistent with this view, anecdotal evidence indicates that Internet firm managers have been paying special attention to reported revenue. More specifically, they have been inflating revenue either by recording sales at their gross rather than net value ("grossing up" revenue) or by recognizing them aggressively, before they were earned. Priceline.com Inc., for 
example, has been criticized for recognizing the entire value of airline tickets sold at its Web site as revenue, rather than merely its commission. This criticism follows because Priceline doesn't "take it [the ticket] into inventory until we know we're going to sell it," with sales occurring in "an hour or less," and thus bears no inventory risk. Howard Schilit, a corporate accounting expert, estimates that Priceline overstated its revenue for the nine months ended September 30, 1999, by $\$ 255$ million: it should have reported $\$ 58$ million in revenue, not \$313 million (see The Wall Street Journal 2000b).

The view that in the absence of positive earnings investors in Internet stocks turn to revenue when valuing Internet stocks is perhaps best highlighted by the following excerpt: "The issue takes on a special significance in the Internet sector because revenues are the lifeblood of these companies and their stocks because earnings often are nonexistent. Investors want growth at Internet firms. When they can't look at earnings, they look for go-go revenue growth."[

The importance revenue plays in the valuation of Internet firms and the problems associated with revenue reporting practices in this industry have not gone unnoticed by regulators. According to The Wall Street Journal (2000b), "A top rule-making panel at the Financial Accounting Standards Board is considering whether the rules should be changed to restrict Internet businesses from including in revenue figures the entire value of product sales or services they arrange between suppliers and buyers online. To the Securities and Exchange Commission and the FASB, it is called 'grossing up' revenue. To many dot-com companies, it is a vital part of their financial health, at a time when they have no profits to show."

The view that in the absence of positive earnings investors in Internet stocks turn to revenue when valuing Internet stocks is perhaps best highlighted by the following excerpt,

\footnotetext{
${ }^{7}$ The Wall Street Journal (2000a).
} 
"The issue takes on a special significance in the Internet sector because revenues are the lifeblood of these companies and their stocks because earnings often are nonexistent. Investors want growth at Internet firms. When they can't look at earnings, they look for go-go revenue growth."

We use two revenue-based variables: sales per share for the year just prior to the IPO (SALESPS) and annualized sales growth in the years prior to the IPO (SGR). We expect a positive association between the dependent variables and our revenue metrics. We also expect this association to be stronger for Internet firms because of the widespread use of revenue multiples rather than earnings or cash flows in valuing such firms.

\section{Book Values}

In addition to the "flow" variables discussed above, we also include one stock variable, book value of equity. Research in Internet valuation (see, e.g., Hand 2000a) has indicated that negative book values may have very different valuation implications than positive book values. Negative book values may indicate investments in R\&D and other intangibles over the years leading to the IPO and thus may be valued by the stock market. To consider this possibility, we break up book value into positive and negative components using a dummy variable.

We expect positive book values to exhibit stronger association with the dependent variables for non-Internet firms than for Internet firms, as book values of the former are less affected by unrecorded intangibles. Furthermore, if investors consider negative book values of Internet firms to reflect primarily unrecorded intangibles, we expect negative book values of these firms to have a negative association with both dependent variables.

\footnotetext{
${ }^{8}$ The Wall Street Journal (2000a).
} 


\subsection{RELATION BETWEEN IPOPRICE AND ENDPRICE AND NON-FINANCIAL VARIABLES}

\section{FLOAT}

FLOAT represents the amount of shares sold in the IPO as a percentage of total shares outstanding. We expect FLOAT to be negatively associated with the two dependent variables for three, not mutually exclusive, reasons. One reason simply pertains to the supply and demand hypothesis that stocks with lesser supply are likely to be priced higher (Shleifer 1986). Second, low FLOAT means greater relative insider ownership, which should be a positive signal to underwriters and investors because it indicates that the IPO is not simply a vehicle for the founders to bail out (see Leland and Pyle 1977). Third, greater insider ownership may be viewed as good news because it implies lower agency costs, as the interests of managers and shareholders are better aligned.

In addition, we expect the negative association between FLOAT and the two dependent variables to be stronger for Internet firms, particularly in the regressions for ENDPRICE. This is largely because of the greater information asymmetry surrounding the valuation of Internet IPOs due to this industry's short history and limited availability of firmspecific financial information vis-à-vis IPOs of firms in more mature industries. This should lead investors and perhaps even underwriters to rely more heavily on signals indicating the unobservable superior information of the entrepreneurs about the prospects of their firms.

\section{PARTIAL}

For the regressions for ENDPRICE, we include an additional non-financial variable, PARTIAL. This variable measures the position of the final offer price relative to the expected price at the time the prospectus was filed (i.e., the midpoint of the range of the offer price disclosed in the prospectus). We add this variable because prior research discussed above has 
shown theoretically (see Benveniste and Spindt 1989) and empirically (see Hanley 1993) that this variable is an important predictor for IPOs' first-day stock price performance. Specifically, this prior research has demonstrated that IPOs priced toward the upper bound of their offer range are likely to be more underpriced than other IPOs. Given this finding, we expect the association between ENDPRICE and PARTIAL to be positive.

In addition, we expect the positive association between ENDPRICE and FLOAT to be stronger for Internet firms, because PARTIAL indicates the expected level of underpricing formed on the basis of the information gathered by the underwriter during the waiting period. Since Internet IPOs have short histories and limited financial information vis-à-vis IPOs of firms in more mature industries, the price uncertainty surrounding Internet IPOs is higher. When valuing Internet IPOs investors are thus expected to attempt to alleviate this increased price uncertainty by relying more heavily on such indirect signals as PARTIAL.

\section{Data}

\subsection{SAMPLE SELECTION}

Our sample covers the 42-month period from January 1996 to June 1999. Our sample period begins in January 1996 because there were hardly any Internet firms in the public domain before that time (see Table 2). The list of Internet firms was obtained from WWW.Internet.com a well-established Web site for information on all aspects of Internet firms as well as IPO information for both Internet and non-Internet firms. This Web site classifies a firm as an Internet firm primarily on the basis of the 51-percent test (i.e., if 51 percent or more of its revenues come from the Internet). The purpose of this test is to distinguish between "pure play" Internet companies that would not have existed without the Internet and other companies generating some revenues from the Internet that would have existed (or did exist) 
without it.

Table 3 summarizes the effects of the sample-selection criteria on the sample size. The initial sample taken from www.Internet.com consists of 233 Internet companies that filed an IPO prospectus with the SEC during our sample period. We dropped 22 firms as they cancelled their plan to go public, reducing our sample size to 211 firms that went public during our sample period. We dropped 21 firms due to our inability to find their IPO prospectus, from which we obtained financial information, decreasing the sample size to 190 firms. We lost 23 firms because we were unable to obtain their CUSIPs needed for retrieving their day 1 end stock price, and we lost an additional 17 firms due to missing information in the prospectus required for the calculation of sales growth, reducing the sample size to 150 .

We attempted to match the remaining 150 firms to non-Internet but otherwise similar firms using the following two criteria: (1) the IPO date, and (2) the IPO size (defined as the product of the number of shares offered and the final offer price). Criterion (1), requiring that the date of the Internet IPO and that of its match be within three days of each other, is meant to control for possible time-period and stock-market-wide effects. Criterion (2) is meant to control for a possible size effect.

We were unable to find matches for 39 of the 150 firms, leaving us with 111 Internet firms. For 11 of these 111 firms, we were unable to find a valid day 1 end price, either because it was not available or because more than one day elapsed between the day of the IPO and the first trading day. This left us with 100 Internet firms for our tests.

\subsection{DESCRIPTIVE STATISTICS}

Table 4 provides descriptive statistics for our sample firms for Internet firms and nonInternet firms separately. Panel A gives descriptive statistics for firm characteristics. We note that, despite our efforts to minimize differences through the matching procedure, there 
remain marked differences between the test and control samples with respect to firm size and profitability. Specifically, while, as expected, all sample IPO firms are relatively small, Internet IPO firms are statistically significantly smaller than their non-Internet counterparts. For example, the means of Sales and Total Assets are, respectively, \$11.24 and \$29.81 for the Internet sample, vis-à-vis \$172.35 and \$282.91 respectively for the non-Internet sample (all figures in millions). In addition, Internet firms have, on average, statistically significantly fewer employees than non-Internet firms (193 employees vs. 1048 employees). This difference may follow (partially) because Internet firms are designed to run virtual operations. Internet firms are also statistically significantly less profitable and generate less cash from operations than their non-Internet matches: the means of Net Income and Cash from Operations for the former are, respectively, $\$-7.17$ and $\$-4.50$, and $\$-2.12$ and $\$ 16.97$ for the latter (all figures in millions).

Still, our matching procedure is successful in generating test and control samples that are similar in certain offer characteristics. Both sets of firms had, on average, around 22 million shares outstanding before the IPO, and Internet IPOs are only slightly smaller than non-Internet IPOs in terms of number of shares offered (3.83 million vs. 5.62 million). The IPO price range (i.e., the difference between the minimum and maximum anticipated offer prices disclosed in the prospectus) and the minimum and maximum offer prices themselves are also very similar. The mean IPO offer price is $\$ 13.31$ for Internet firms and $\$ 11.95$ for non-Internet firms. The average day 1 end price, however, is higher for Internet firms $(\$ 24.41$ vs. \$14.75). Thus, while the market reacts positively, on average, to all IPOs in their debut (the well-known underpricing phenomenon), this positive reaction is more pronounced for Internet IPOs than for non-Internet IPOs.

Panel B of Table 4 provides descriptive statistics for the explanatory variables used in 
our regressions. The differences between Internet firms and non-Internet firms with respect to the per-share values of sales, book values, earnings, and cash from operations are in the same direction as those observed in Panel A, which reported the nonscaled values of these variables. In brief, on a per share basis Internet companies are smaller and less profitable than their non-Internet counterparts. The data in Panel B further indicate that Internet IPO firms exhibit statistically significantly greater annual sales growth than non-Internet firms $(89.7 \%$ vs. $36.8 \%)$.

The two samples also differ significantly with respect to FLOAT (the mean percentage of shares offered in the IPO). FLOAT is statistically significantly lower for Internet firms (23.5\% vs. 30.7\%). Finally, Internet (non-Internet) firms have mean PARTIAL of 1.068 (0.996). This implies that underwriters initially have an unbiased or perhaps even somewhat optimistic estimate of the final offer price of non-Internet IPOs. ${ }^{-2}$ Conversely, for Internet IPOs, whose final offer prices are likely to be above the midpoints of their price ranges, underwriters initially underestimate investors' demand for these stocks, an indication of the optimism and momentum surrounding Internet IPOs for the time period being analyzed.

\subsection{CORRELATIONS AMONG THE EXPLANATORY VARIABLES}

Table 5 reports pair-wise correlations between all independent variables used in the regressions. Panels A and B present correlations for Internet and non-Internet firms, respectively. Figures above (below) the diagonal are Pearson (Spearman-rank-order) correlations.

For Internet firms, earnings per share (EPS) and cash flow per share (CFOPS) are very

\footnotetext{
${ }^{9}$ Recall that PARTIAL measures the position of the IPO final offer price relative to its price range as disclosed in the prospectus. It is computed as the IPO offer price divided by the midpoint of the IPO range. A value of one thus means that the final offer price equals the midpoint of the IPO price range.
} 
highly correlated (Spearman correlation, 0.618). These variables are our alternative performance measures and are never used in the same regression. No other correlation exceeds 0.3 in absolute magnitude. For non-Internet firms, there are strong correlations among all of the three alternative performance measures: EPS and CFOPS (Spearman correlation, 0.427), CFOPS and SALESPS (Spearman correlation, 0.437), and EPS and SALESPS (Spearman correlation, 0.374). The other strong correlation is between FLOAT and BVPS (Pearson correlation, 0.390). For both samples, PARTIAL is negatively correlated with FLOAT, indicating that the extent of underpricing is likely to be greater when a firm sells relatively fewer shares. Overall, the relatively low correlations among the explanatory variables used simultaneously in the regressions increase confidence that multicollinearity is not a serious problem for our data.

\section{Tests and Results}

\subsection{REGRESSIONS FOR IPOPRICE}

Table 6 presents the regression results for IPOPRICE. We estimate three alternative specifications with earnings, cash flows, and sales as our performance measures. The dependent variables and all financial explanatory variables are expressed on a per share basis. 10 The regressions are carried out separately for the two subsamples of Internet and non-Internet firms. F Tests are performed to calculate the significance of the differences in the coefficient estimates between Internet firms and non-Internet firms. 1 We include a

\footnotetext{
${ }^{10}$ In an effort to alleviate heteroskedasticity, we use shares outstanding as the deflator. Tests for heteroskedasticity fail to reject the null of homoskedasticity for all models. Note that our sample firms have large unrecorded intangible assets, which make total assets an inappropriate deflator. Indeed, when total assets are used as a deflator, homoskedasticity is rejected.

${ }^{11}$ To test the differences between coefficients, we re-estimate the regression using the entire sample and interacting each explanatory variable with a dummy variable for Internet and non-Internet firms. For each
} 
dummy variable, POST98, in all specifications to test for a possible effect of the "Internet craze" that started in early 1999.

Results for the first specification, with earnings as the performance variable, indicate that none of the financial variables is significant for either Internet firms or non-Internet firms. While we did not expect earnings or book values to be significant for Internet firms, the results for non-Internet firms are somewhat surprising. We revisit this matter later, when we partition our sample into two time periods. As expected, FLOAT is significantly negative for both Internet and non-Internet firms, and the coefficient is of significantly larger magnitude for Internet firms. Sales Growth (SGR) is significant for Internet firms and insignificant for non-Internet firms. The dummy variable, POST98, is significantly positive only for Internet firms and has a coefficient of 2.29. This indicates that an Internet firm with the same financials and FLOAT commanded an IPO offer price that was \$2.29 higher per share in 1999 than before that period, which is consistent with the euphoria surrounding the Internet industry in 1999.

The second regression uses cash flows as the performance measure. The coefficient on positive cash flow (POSCFO) is significant for both Internet and non-Internet firms. Thus, while earnings do not seem to matter for IPOs in our sample, cash flows are important for both classes of firms. Interestingly, the coefficient on POSCFO is significantly greater for Internet firms, reflecting the greater multiple that Internet firms receive for their cash flows. In addition, for Internet firms the coefficient on negative cash flow (NEGCFO) is significantly negative, while for non-Internet firms this coefficient is insignificant. This indicates that underwriters and sophisticated investors do consider negative cash flows to be

explanatory variable we thus obtain two coefficient estimates, one for the Internet firms and the other for nonInternet firms. We then use an $\mathrm{F}$ test to test for equality between these two estimates. 
akin to investments for Internet firms, potentially because these firms spend large amounts on cash outlays for infrastructure developments that are expected to yield high returns in the future. As before, FLOAT has a negative coefficient that is much more pronounced for Internet firms (the difference is highly statistically significant). Sales growth continues to be significant for Internet firms and insignificant for non-Internet firms, as is POST98.

The final regression uses sales per share (SALESPS) as the performance measure. SALESPS is not partitioned, as it is always nonnegative. The estimate on SALESPS is positive and significant for both Internet and non-Internet firms. As expected, the coefficient on SALESPS is significantly greater for Internet firms than for non-Internet firms. This implies that underwriters use higher sales multiples to value IPOs of Internet firms than other IPOs. Sales growth (SGR) continues to be significant only for Internet firms. As before, FLOAT is significantly negative for both samples and significantly greater in magnitude for Internet firms, and POST98 is significantly positive only for the Internet firms.

To summarize, from the underwriter viewpoint positive cash flows and sales are the important financial variables and FLOAT is the critical non-financial variable for both Internet and non-Internet firms. In addition, Internet firms' negative cash flows are viewed as investments, and their sales growth is important, perhaps due to their rapid growth. As expected, the valuation effects of both sales and FLOAT on the IPO offer price are stronger for Internet firms than for non-Internet firms. The only unexpected result is the insignificance of the two financial variables, earnings and book values, for non-Internet firms.

\subsection{REGRESSIONS FOR ENDPRICE}

ENDPRICE is the closing stock price at the end of the first trading day as defined by CRSP, which is typically the average of the closing bid and ask prices. As before, we run three alternative specifications with earnings, cash flows, and sales as our alternative 
performance measures. We add an additional explanatory variable, PARTIAL, to capture the "sentiment" of sophisticated investors toward the IPO during the waiting period.

Table 7 presents the regression results for ENDPRICE. Earnings remain insignificant for both Internet and non-Internet firms. The other two performance measures, cash flows and sales, are no longer significant. In addition, positive book value (POSBV) remains insignificant for the non-Internet firms but becomes significantly positive in all three specifications for Internet firms. Why would positive book values be rewarded by the stock market for Internet firms, especially when they are so rare (the mean and median book value per share for Internet firms was \$-0.07 and \$0.06)? One explanation is that positive book values proxy for long-term financial health (i.e. the risk of bankruptcy is lower). ${ }^{12}$ This indicator is particularly important for Internet firms due to the higher uncertainty surrounding the future of this new industry.

Sales growth (SGR) has a significant positive coefficient in all specifications for both Internet firms and non-Internet firms. As expected, the coefficient on Internet firms is significantly greater, indicating that the stock market attaches a higher multiple for sales growth for Internet firms.

FLOAT has significantly negative coefficients in all specifications. This implies that, like underwriters, investors consider the percentage of shares offered in an IPO an important value indicator. Ceteris paribus, the lower the percentage, the higher the firm value is. As we hypothesized, this effect is statistically significantly stronger for Internet firms than for nonInternet firms.

In addition, consistent with findings of prior research, the additional explanatory

\footnotetext{
${ }^{12}$ One way to test this is to compare the correlations between pre-IPO cash balances and positive book values (POSBV) for Internet and non-Internet firms. This correlation was 0.15 for non-Internet firms and 0.38 for Internet firms, indicating that POSBV may proxy for financial health in terms of liquidity.
} 
variable, PARTIAL, is positive and highly significant in all three specifications. Furthermore, as expected, PARTIAL has a significantly higher coefficient for Internet firms, indicating the strong momentum surrounding Internet stocks in the time period analyzed.

Finally, the dummy variable, POST98, is significantly positive for both Internet and non-Internet firms in all three specifications. The regression results indicate that, relative to the pre-1999 sample period, the ENDPRICE in 1999 was higher by $\$ 4.24$ to $\$ 4.72$ for Internet firms and by $\$ 2.76$ to $\$ 2.97$ for non-Internet firms. This observed increase in ENDPRICE between the two sample periods was also significantly greater for Internet firms than for non-Internet firms. This indicates that the first day reaction was stronger across the board for all IPOs in early 1999, and more so for Internet firms.

Thus, among the financial variables we examine, investors rely on sales growth and book value when evaluating Internet IPOs, unlike underwriters, who rely on sales and cash flows. For non-Internet firms, the valuation approaches of investors and underwriters also differ. While the former rely only on sales growth, the latter continue to draw on both positive cash flows and sales. In other words, two differences between underwriters and investors emerge: (1) underwriters and investors draw on different financials when valuing IPOs, and (2) while underwriters consistently draw on the same two financials, investors use two variables for valuing Internet firms but only one for non-Internet firms. With respect to the non-financial variables, as expected, both underwriters and investors rely on FLOAT, and investors also rely on PARTIAL.

One intriguing result, particularly for non-Internet firms, is that neither underwriters nor investors draw on earnings when valuing IPOs. In the next section, we thus re-estimate some of our regression tests with interaction dummy variables for a possible time-period effect on earnings. As explained below, this may provide insights into why earnings are 
insignificant in the regressions above.

\subsection{REGRESSIONS WITH TIME INTERACTIONS}

1999 can be characterized as one of hectic activity in terms of Internet IPOs. As Table 2 indicates, as many as 192 Internet firms went public in 1999, more than four times the number in 1998 (42 firms). As the regressions in the previous section show, in 1999 both underwriters and investors valued Internet IPOs higher than in the pre-1999 period. One possible contributing factor for this finding is that investors in 1999 viewed Internet firms as a modern-day version of a "gold rush." This euphoria may have resulted in valuations not tied to earnings. To test whether this time-period phenomenon affected the earnings-price relation, we interact earnings with POST98, a dummy variable that is set to 0 for all IPOs going public on or before December 31, 1998, and 1 thereafter.

Table 8 presents the regression results for both IPOPRICE and ENDPRICE. For Internet firms, POSEPS for both IPOPRICE and ENDPRICE is insignificant in both sample periods. In contrast, for non-Internet firms POSEPS has a significantly positive coefficient and POSEPS*POST98 has a significantly negative coefficient for both IPOPRICE and ENDPRICE. Hence, from the perspectives of both underwriters and investors, positive earnings of Internet firms play no role in valuation in both subperiods, whereas positive earnings of non-Internet firms were significant in the early sample period but completely lost their significance in the later period. This loss of significance is responsible for earnings being insignificant in our earlier regression for IPOPRICE for non-Internet firms. ${ }^{13}$

Why did underwriters and investors stop relying on earnings when valuing nonInternet firms in the later period? One possible explanation is that in this time period market

\footnotetext{
${ }^{13}$ Re-estimating the regression for IPOPRICE by subperiod, using earnings as the sole explanatory variable, generates an adjusted $\mathrm{R}^{2}$ of $16.5 \%$ in the early period (1996-1998) and less than $1 \%$ in the later period (1999).
} 
participants abandoned earnings altogether, mimicking valuations of Internet firms for all firms. A second explanation is that, following the lead of Internet firms and the market exuberance in 1999, non-Internet firms went public early in their life cycles, when their earnings and book values were less value-relevant.

To further investigate this second explanation, Table 9 compares the characteristics of firms in the two time periods. In the later period, non-Internet firms have significantly greater cash flows (CFOPS), and there is no evidence that any of the other variables decline in value. This is inconsistent with the explanation that in the later period the non-Internet firms were also early-stage companies. In fact, it appears that the market was so skewed towards Internet IPOs that non-Internet firms needed to be larger and more profitable than before in order to go public.

\subsection{SENSITIVITY TEST: CONTROLLING FOR FIRM SIZE}

One potential omitted variable in our analyses is firm size. If larger firms are likely to have a larger IPO price and larger day 1 end price, regressing these variables on financial variables may generate spurious correlations. In our regressions, we attempt to address this potential problem by measuring all financial variables on a per share basis. To assess the sensitivity of our results to firm size, we augment our regressions by adding a size control variable, defined as either the $\log$ of sales or the $\log$ of assets. The results (not reported) are essentially unchanged.

\section{Conclusion}

We examine financial and non-financial value drivers of Internet and matched nonInternet companies from two perspectives. First, we identify variables that underwriters and entrepreneurs consider important in setting the IPO offer price by examining value drivers 
underlying the IPO offer price. Second, we identify variables that the broader market or small investors consider important in pricing the IPO stock by investigating the value drivers of the stock price at the end of the first trading day. We contrast valuations of Internet IPO firms and non-Internet, but otherwise similar, IPO firms (i.e., a control sample), as well as valuations in early (1996-1998) and late (1999) time periods, and document the differences.

Our primary conclusions are as follows. First, from the viewpoint of the underwriters and the issuing firms, the important value drivers underlying IPO Internet firms are the relative size of the offering, sales, sales growth, and both positive and negative cash flows; negative cash flows are important because they are viewed as investments. For non-Internet firms, the relative offering size, sales, and positive cash flows are important drivers. The effect of relative offering size is much stronger for Internet firms.

Second, from the viewpoint of investors, the important value drivers of Internet firms are book values, sales growth, the relative size of the offering, and a variable reflecting the information gathered by the underwriter during the IPO period. For non-Internet firms, the value drivers are sales growth, relative offering size, and the information gathered by the underwriter. The last two variables are stronger drivers for Internet firms than for nonInternet firms. Interestingly, from the standpoint of both underwriters and investors, earnings seem to play no role in valuing IPOs.

Replicating the analyses by early (1996 - 1998) and late (1999) subperiods indicates a shift away from earnings in 1999 for non-Internet firms. Before 1999, earnings played a significant role in setting both the IPO offer price and the day 1 end price of non-Internet firms. The role of earnings in valuation of these firms, however, completely disappeared in 1999. One plausible explanation for this is that in 1999 the stock market mimicked the valuation of Internet stocks--for which earnings never appear to be important--when valuing 
non-Internet stocks. This suggests an interesting avenue for future research. By examining valuations of IPOs of Internet and non-Internet firms after the meltdown of the Internet industry, one can study whether underwriters and investors returned to earnings once the "Internet craze" subsided. 


\section{REFERENCES}

Benveniste, L.M., and P.A. Spindt. 1989. "How investment bankers determine the offer price and allocation of new issues." Journal of Financial Economics 24, 33-361.

Demers, E., and B. Lev. 2000. “A rude awakening: Internet shakeout in 2000.” Working paper, University of Rochester.

Business Week. 1998. “Internet stocks: what's their real worth?” December 14.

Hand, J.R.M. 2000a. "Profits, losses and the non-linear pricing of Internet stocks." Working paper, University of North Carolina, Chapel Hill.

Hand, J.R.M. 2000b. "The role of accounting fundamental, web traffic, and supply and demand in the pricing of U.S. Internet stocks." Working paper, University of North Carolina, Chapel Hill.

Hayn, C. 1995. "The information content of losses." Journal of Accounting and Economics 20, 125-153.

Ibbotson, R.G., and J. Ritter. 1995. Initial public offerings, in R. Jarrow et al. Editors. Handbook in Operations Research and Management Science 9, Elsevier B.V.

Leland, H.E., and D.H. Pyle. 1977. "Informational asymmetries, financial structure, and financial intermediation." The Journal of Finance 32, 371-387.

Schwartz, E.S., and M. Moon. 2000. "Rational pricing of Internet companies." Financial Analyst Journal 56, 62-75.

Shleifer, A. 1986. "Do demand curves for stocks slope down?" The Journal of Finance 41, 579-590.

Trueman, B., M.H.F. Wong, and X.J. Zhang. 2000. "The eyeballs have it: searching for the value in Internet stocks." Journal of Accounting Research, forthcoming.

The Wall Street Journal. 1999. "Too hot an IPO? Andover.net's 252\% pop raises questions about underwriters Dutch auction." December 9, C1.

The Wall Street Journal. 2000a. "Is healtheon pushing limits on revenue?" February 7, C1.

The Wall Street Journal. 2000b. "Plump from Web sales, some dot-coms face crash diet of restriction on booking revenue." February 28, C4. 
Table 1

Summary of Hypotheses: Relation between the Two Dependent Variables, IPOPRICE and ENDPRICE, and the Explanatory Variables

\begin{tabular}{|l|c|c|l|}
\hline DRIVER & $\begin{array}{c}\text { Internet } \\
\text { Firms }\end{array}$ & $\begin{array}{c}\text { Non-Internet } \\
\text { Firms }\end{array}$ & $\begin{array}{l}\text { Differences across } \\
\text { categories }\end{array}$ \\
\hline Positive EARNINGS & $?$ & + & $\begin{array}{l}\text { Stronger for Non-Internet } \\
\text { More negative for Internet }\end{array}$ \\
Negative EARNINGS & - & $?$ & Stronger for Non-Internet \\
Positive CASH FLOW & $?$ & + & More negative for Internet \\
Negative CASH FLOW & - & $?$ & Stronger for Internet \\
SALES & + & + & Stronger for Internet \\
SALES GROWTH & + & + & Stronger for Non-Internet \\
Positive BOOK VALUE & $?$ & $?$ & More negative for Internet \\
Negative BOOK VALUE & - & - & Stronger for Internet \\
FLOAT & - & & \\
PARTIAL (ENDPRICE & + & & \\
only) & & & \\
\hline
\end{tabular}

$\underline{\text { Variable definitions }}$

$\begin{array}{ll}\text { ENDPRICE } & \text { Day 1 End Price } \\ \text { IPOPRICE } & \text { The IPO final offer price } \\ \text { FLOAT } & \text { Percentage of shares outstanding offered in the IPO } \\ \text { PARTIAL } & \text { Offer price scaled by the midpoint of the offer range }\end{array}$


Table 2

IPOs in the Ten-Year Period 1990-1999

\begin{tabular}{|c|r|r|r|r|}
\hline & \multicolumn{2}{|c|}{ All firms $^{1}$} & \multicolumn{2}{c|}{ Internet firms $^{2}$} \\
\cline { 2 - 5 } Year & $\begin{array}{r}\text { Number of } \\
\text { offerings }\end{array}$ & $\begin{array}{r}\text { Dollar value } \\
\text { (millions) }\end{array}$ & $\begin{array}{r}\text { Number of } \\
\text { offerings }\end{array}$ & $\begin{array}{r}\text { Dollar value } \\
\text { (millions) }\end{array}$ \\
\hline 1990 & 158 & $4,627.20$ & 1 & 50.40 \\
1991 & 380 & $16,350.29$ & 0 & 0.00 \\
1992 & 528 & $29,359.18$ & 2 & 64.60 \\
1993 & 628 & $38,524.67$ & 0 & 0.00 \\
1994 & 539 & $31,619.41$ & 2 & 46.40 \\
1995 & 557 & $31,769.75$ & 2 & 86.44 \\
1996 & 786 & $36,955.88$ & 19 & 484.72 \\
1997 & 603 & $38,449.88$ & 29 & 853.69 \\
1998 & 362 & $49,992.37$ & 42 & $2,132.32$ \\
1999 & 545 & $104,982.06$ & 192 & $14,247.42$ \\
Total & 5,086 & $382,630.69$ & 289 & $17,965.99$ \\
\hline
\end{tabular}

${ }^{1}$ Data source: www.marketdata.nasdaq.com

${ }^{2}$ Data source: www.Internet.com (1996-1998) and www.Internetnews.com (rest of the years) 
Table 3

Sample Selection

\begin{tabular}{|l|l|}
\hline \multicolumn{1}{|c|}{ Criterion } & $\begin{array}{l}\text { Number } \\
\text { of firms }\end{array}$ \\
\hline $\begin{array}{l}\text { Internet IPOs between 1/96 and 6/99, } \\
\text { listed on www.Internet.com }\end{array}$ & 233 \\
$\begin{array}{l}\text { Withdrawn } \\
\text { Internet IPOs that went public }\end{array}$ & $\frac{22}{211}$ \\
$\begin{array}{l}\text { IPO prospectus unavailable } \\
\text { Internet IPOs that went public with } \\
\text { prospectus available }\end{array}$ & $\frac{21}{190}$ \\
$\begin{array}{l}\text { CUSIP unavailable } \\
\text { IPO data required for the analysis are } \\
\text { unavailable from the prospectus } \\
\text { Internet IPOs that went public with } \\
\text { available data for offer price regressions } \\
\text { An IPO match unavailable }\end{array}$ & 23 \\
$\begin{array}{l}\text { Internet IPOs with valid matches as well } \\
\text { as offer price }\end{array}$ & $\frac{17}{150}$ \\
$\begin{array}{l}\text { Valid day-one-end price unavailable } \\
\text { SAMPLE for our regressions }\end{array}$ & $\frac{39}{111}$ \\
\hline
\end{tabular}

${ }^{1}$ Firms were matched on IPO date and IPO size in dollars. 
Table 4

Panel A: Firm Characteristics

\section{Descriptive Statistics}

\begin{tabular}{|c|c|c|c|c|c|c|}
\hline \multirow[b]{2}{*}{ Variable } & \multicolumn{2}{|c|}{ Internet $(\mathrm{n}=100)$} & \multicolumn{2}{|c|}{ Non-Internet $(\mathrm{n}=100$} & \multicolumn{2}{|c|}{ Difference } \\
\hline & Mean & Median & Mean & Median & $\begin{array}{c}\text { T Stat } \\
\text { (means) }\end{array}$ & $\begin{array}{c}\mathrm{Z} \mathrm{Stat}^{1} \\
\text { (medians) }\end{array}$ \\
\hline Sales & 11.24 & 5.75 & 172.35 & 20.32 & $-2.049^{* *}$ & $-5.84^{* * *}$ \\
\hline Total Assets & 29.81 & 17.37 & 282.91 & 26.52 & $-2.289^{* *}$ & $-3.32^{* * * *}$ \\
\hline Net Income & -7.17 & -3.86 & -2.12 & 0.09 & $-1.748^{*}$ & $-5.98^{* * *}$ \\
\hline Cash from Operations & -4.50 & -2.23 & 16.97 & 0.29 & $-2.604^{* * *}$ & $-5.90^{* * *}$ \\
\hline Book Value of Equity & -0.39 & 1.25 & 11.05 & 1.31 & -0.855 & -1.21 \\
\hline $\begin{array}{l}\text { Number of Shares } \\
\text { Outstanding (millions) }\end{array}$ & 22.03 & 16.27 & 22.18 & 13.30 & -0.034 & $-1.82^{*}$ \\
\hline Number of Employees & 193 & 135.00 & 1048 & 226.00 & $-2.212^{* *}$ & $-4.00^{* * *}$ \\
\hline FLOAT & $23.5 \%$ & $21.8 \%$ & $30.7 \%$ & $28.6 \%$ & $-3.755^{* * *}$ & $-3.63^{* * *}$ \\
\hline IPOPRICE & 13.31 & 13.00 & 11.95 & 12.00 & $2.158^{* *}$ & $1.95^{*}$ \\
\hline $\begin{array}{l}\text { Number of Shares Offered } \\
\text { (millions) }\end{array}$ & 3.83 & 3.40 & 5.62 & 3.30 & $-1.684^{*}$ & -0.003 \\
\hline ENDPRICE & 24.41 & 17.00 & 14.75 & 13.38 & $4.805^{* * *}$ & $3.65^{* * *}$ \\
\hline IPO Offer Price Range & 1.74 & 2.00 & 1.67 & 2.00 & 0.693 & -0.59 \\
\hline IPO Min. Offer Price & 11.53 & 11.00 & 11.23 & 11.00 & 0.533 & 0.18 \\
\hline IPO Max. Offer Price & 13.27 & 13.00 & 12.90 & 13.00 & 0.607 & 0.20 \\
\hline
\end{tabular}

Panel B: Summary Statistics for Regression Variables Internet $(\mathbf{n}=\mathbf{1 0 0})$

Non-Internet $(\mathbf{n}=\mathbf{1 0 0})$

Difference

\begin{tabular}{|l|c|c|c|c|c|c|}
\hline Variable & Mean & Median & Mean & Median & $\begin{array}{c}\text { T Stat } \\
\text { (Means) }\end{array}$ & $\begin{array}{c}\text { Z Stat }^{1} \\
\text { (Medians) }\end{array}$ \\
\hline SALESPS & 1.26 & 0.70 & 6.99 & 2.99 & $-4.89^{* * * *}$ & $-7.80^{* * * *}$ \\
EPS & -0.67 & -0.61 & -0.11 & 0.05 & $-4.80^{* * *}$ & $-6.26^{* * * *}$ \\
CFOPS & -0.41 & -0.39 & 0.45 & 0.06 & $-5.28^{* * *}$ & $-6.02^{* * *}$ \\
BVPS & -0.06 & 0.12 & 0.39 & 0.12 & $-1.98^{* *}$ & 1.25 \\
SGR & $89.7 \%$ & $75.4 \%$ & $36.8 \%$ & $35.4 \%$ & $3.50^{* * *}$ & $5.70^{* * *}$ \\
FLOAT & $23.5 \%$ & $21.8 \%$ & $30.7 \%$ & $28.6 \%$ & $-3.76^{* * *}$ & $-3.63^{* *}$ \\
PARTIAL & 1.068 & 1.077 & 0.996 & 1.000 & $4.02^{* * *}$ & $4.69^{* * *}$ \\
\hline
\end{tabular}

All variables are measured using the most recent annualized data from IPO prospectus. Sales, Total Assets, Net Income, Cash from Operations and Book Value are in millions of dollars. Shares Outstanding are measured immediately after the IPO.

${ }^{1} \mathrm{Z}$ Statistic is computed using the Wilcoxon Signed Rank test for difference in medians.

${ }_{* * *}^{* * *}$ Significant at the $1 \%$ level using a two-tailed test.

** Significant at the 5\% level using a two-tailed test.

* Significant at the $10 \%$ level using a two-tailed test.

\section{Definition of Variables}

EPS Earnings per share for the year just prior to the IPO

CFOPS

SALESPS

BVPS

FLOAT

SGR

PARTIAL
Cash Flow From operations per share for the year just prior to the IPO

Sales per share for the year just prior to the IPO

Book Value per share for the year just prior to the IPO

Percentage of shares outstanding offered in the IPO

Annual Sales Growth in the years prior to the IPO

Offer price scaled by the midpoint of the offer range 
Table 5

Correlation Matrix--Pearson Correlations above Diagonal and Spearman-Rank Correlations below Diagonal

Panel A: Internet Firms $(\mathrm{n}=100)$

\begin{tabular}{|l|c|c|c|c|c|c|c|}
\hline & SALESPS & EPS & CFOPS & BVPS & SGR & FLOAT & PARTIAL \\
\hline SALESPS & & 0.057 & -0.115 & 0.109 & $-0.175^{*}$ & 0.069 & -0.078 \\
EPS & $0.170^{*}$ & & $0.554^{* * *}$ & 0.154 & -0.088 & 0.041 & $0.234^{*}$ \\
CFOPS & 0.009 & $0.618^{* * *}$ & & $0.204^{* *}$ & -0.045 & -0.019 & 0.136 \\
BVPS & 0.044 & 0.154 & 0.154 & & -0.014 & $-0.188^{*}$ & 0.005 \\
SGR & $-0.282^{* * *}$ & -0.091 & -0.020 & 0.068 & & $-0.194^{* *}$ & $0.244^{* *}$ \\
FLOAT & 0.095 & 0.052 & -0.021 & -0.115 & $-0.334^{* * *}$ & & $-0.203^{* *}$ \\
PARTIAL & -0.030 & 0.109 & 0.071 & -0.065 & 0.090 & $-0.238^{* *}$ & \\
\hline
\end{tabular}

Panel B: Non-Internet Firms $(\mathrm{n}=100)$

\begin{tabular}{|l|c|c|c|c|c|c|c|}
\hline & SALESPS & EPS & CFOPS & BVPS & SGR & FLOAT & PARTIAL \\
\hline SALESPS & & 0.060 & $0.459^{* * *}$ & 0.000 & -0.085 & $0.225^{* *}$ & $-0.174^{*}$ \\
EPS & $0.374^{* * *}$ & & $0.296^{* * *}$ & $0.289^{* * *}$ & -0.085 & 0.090 & 0.073 \\
CFOPS & $0.437^{* * *}$ & $0.427^{* * * *}$ & & $0.168^{*}$ & -0.017 & $0.221^{* *}$ & -0.065 \\
BVPS & 0.050 & $0.316^{* * *}$ & $0.232^{* * *}$ & & -0.004 & $0.390^{* * *}$ & -0.041 \\
SGR & -0.140 & -0.146 & -0.109 & 0.031 & & -0.094 & 0.058 \\
FLOAT & $0.179^{*}$ & 0.108 & 0.098 & 0.003 & $-0.189^{*}$ & & $-0.218^{* *}$ \\
PARTIAL & $-0.235^{* *}$ & -0.040 & -0.038 & -0.076 & $0.203^{* *}$ & $-0.258^{* * * *}$ & \\
\hline
\end{tabular}

${ }^{* * * *}$ Significant at the $1 \%$ level using a two-tailed test.

** Significant at the 5\% level using a two-tailed test.

* Significant at the $10 \%$ level using a two-tailed test.

\section{Definition of Variables}

EPS Earnings per share for the year just prior to the IPO

CFOPS

SALESPS

Cash Flow From operations per share for the year just prior to the IPO

BVPS

FLOAT

SGR

Book Value per share for the year just prior to the IPO

PARTIAL

Percentage of shares outstanding offered in the IPO

Annual Sales Growth in the years prior to the IPO

Offer price scaled by the midpoint of the offer range 
Table 6

Regression for IPO Price

(t-statistics in parentheses, $\mathrm{n}=100$ )

\begin{tabular}{|c|c|c|c|c|c|c|c|c|c|}
\hline & \multicolumn{3}{|c|}{$\begin{array}{c}\text { Model } 1 \\
\text { EARNINGS }\end{array}$} & \multicolumn{3}{|c|}{$\begin{array}{c}\text { Model } 2 \\
\text { CASH FLOW }\end{array}$} & \multicolumn{3}{|c|}{$\begin{array}{l}\text { Model } 3 \\
\text { SALES }\end{array}$} \\
\hline & Internet & $\begin{array}{c}\text { Non- } \\
\text { Internet }\end{array}$ & Diff $^{+}$ & Internet & $\begin{array}{c}\text { Non- } \\
\text { Internet }\end{array}$ & Diff $^{+}$ & Internet & $\begin{array}{c}\text { Non- } \\
\text { Internet }\end{array}$ & Diff $^{+}$ \\
\hline INTERCEPT & $\begin{array}{c}14.84^{* * *} \\
(10.6)\end{array}$ & $\begin{array}{l}12.30^{* * *} \\
(11.29)\end{array}$ & & $\begin{array}{c}13.26^{* * * *} \\
(9.81)\end{array}$ & $\begin{array}{c}12.86^{\text {**** }} \\
(12.17)\end{array}$ & & $\begin{array}{l}14.59^{* * *} \\
(11.33)\end{array}$ & $\begin{array}{c}12.54^{* * * *} \\
(12.27)\end{array}$ & \\
\hline POSEPS & $\begin{array}{l}0.231 \\
(0.08)\end{array}$ & $\begin{array}{l}1.326 \\
(1.17)\end{array}$ & 0.584 & & & & & & \\
\hline NEGEPS & $\begin{array}{l}-0.283 \\
(-0.47)\end{array}$ & $\begin{array}{l}-0.265 \\
(-0.42)\end{array}$ & 0.605 & & & & & & \\
\hline POSCFO & & & & $\begin{array}{c}2.686^{* *} \\
(2.24)\end{array}$ & $\begin{array}{l}0.619^{*} \\
(1.87)\end{array}$ & 0.013 & & & \\
\hline NEGCFO & & & & $\begin{array}{l}-2.306^{* *} \\
(-2.77)\end{array}$ & $\begin{array}{l}0.929 \\
(0.92)\end{array}$ & $<0.01$ & & & \\
\hline SALESPS & & & & & & & $\begin{array}{l}0.352^{*} \\
(1.73)\end{array}$ & $\begin{array}{l}0.10^{* * * *} \\
(2.70)\end{array}$ & $<0.01$ \\
\hline POSBV & $\begin{array}{l}0.421 \\
(0.62)\end{array}$ & $\begin{array}{c}0.15 \\
(0.49)\end{array}$ & 0.456 & $\begin{array}{l}0.618 \\
(0.95)\end{array}$ & $\begin{array}{l}0.156 \\
(0.54)\end{array}$ & 0.486 & $\begin{array}{l}0.321 \\
(0.48)\end{array}$ & $\begin{array}{l}0.182 \\
(0.64)\end{array}$ & 0.530 \\
\hline NEGBV & $\begin{array}{l}-0.29 \\
(-0.52)\end{array}$ & $\begin{array}{l}-0.972 \\
(-1.48)\end{array}$ & 0.228 & $\begin{array}{l}-0.023 \\
(-0.04)\end{array}$ & $\begin{array}{l}-0.892 \\
(-1.39)\end{array}$ & 0.235 & $\begin{array}{l}-0.392 \\
(-0.74)\end{array}$ & $\begin{array}{l}-0.573 \\
(-0.95)\end{array}$ & 0.491 \\
\hline FLOAT & $\begin{array}{c}-16.48^{* * *} \\
(-4.19)\end{array}$ & $\begin{array}{l}-6.82^{* *} \\
(-2.37)\end{array}$ & $<0.01$ & $\begin{array}{c}-15.57^{* * * *} \\
(-4.16)\end{array}$ & $\begin{array}{l}-7.61^{* * * *} \\
(-2.66)\end{array}$ & $<0.01$ & $\begin{array}{c}-16.97^{* * * *} \\
(-4.42)\end{array}$ & $\begin{array}{l}-8.26^{* * *} \\
(-2.92)\end{array}$ & $<0.01$ \\
\hline SGR & $\begin{array}{l}0.863^{*} \\
(1.91)\end{array}$ & $\begin{array}{l}0.914 \\
(1.04)\end{array}$ & 0.046 & $\begin{array}{c}0.871^{* *} \\
(2.04)\end{array}$ & $\begin{array}{l}1.022 \\
(1.2)\end{array}$ & 0.056 & $\begin{array}{c}0.998^{* *} \\
(2.24)\end{array}$ & $\begin{array}{l}1.149 \\
(1.37)\end{array}$ & 0.013 \\
\hline POST98 & $\begin{array}{c}2.288^{* * * *} \\
(2.6)\end{array}$ & $\begin{array}{l}1.141 \\
(1.28)\end{array}$ & $<0.01$ & $\begin{array}{c}2.807^{* * *} \\
(3.33)\end{array}$ & $\begin{array}{l}0.827 \\
(0.94)\end{array}$ & $<0.01$ & $\begin{array}{c}2.304^{* * *} \\
(2.72)\end{array}$ & $\begin{array}{l}1.027 \\
(1.2)\end{array}$ & $<0.01$ \\
\hline Observations & 100 & 100 & & 100 & 100 & & 100 & 100 & \\
\hline Adjusted $\mathrm{R}^{2}$ & $24.91 \%$ & $8.06 \%$ & & $31.97 \%$ & $11.91 \%$ & & $27.77 \%$ & $14.32 \%$ & \\
\hline
\end{tabular}

${ }^{+}$Difference between Internet and non-Internet firms using an $\mathrm{F}$ test (p-value reported).

${ }^{* * * *}$ Significant at the $1 \%$ level using a two-tailed test.

** Significant at the 5\% level using a two-tailed test.

* Significant at the $10 \%$ level using a two-tailed test.

\section{Definition of Variables}

$\begin{array}{ll}\text { POSEPS } & \text { EPS * Dummy for positive earnings } \\ \text { NEGEPS } & \text { EPS * (1-Dummy for positive earnings) } \\ \text { POSCFO } & \text { CFO per share * Dummy for positive cash flow } \\ \text { NEGCFO } & \text { CFO per share * (1- Dummy for positive cash flow) } \\ \text { SALESPS } & \text { Sales per share } \\ \text { POSBV } & \text { Book Value per share * Dummy for positive Book Value } \\ \text { NEGBV } & \text { Book Value per share } * \text { (1-Dummy for positive Book Value) } \\ \text { FLOAT } & \text { Percentage of shares outstanding offered in the IPO } \\ \text { SGR } & \text { Annual Sales Growth in the years prior to the IPO } \\ \text { POST98 } & \text { Dummy Variable for period after Dec } 31,1998\end{array}$


Table 7

Regression for Day 1 End Price

(t-statistics in parentheses, $\mathrm{n}=100$ )

\begin{tabular}{|c|c|c|c|c|c|c|c|c|c|}
\hline & \multicolumn{3}{|c|}{$\begin{array}{c}\text { Model } 1 \\
\text { EARNINGS }\end{array}$} & \multicolumn{3}{|c|}{$\begin{array}{c}\text { Model } 2 \\
\text { CASH FLOW }\end{array}$} & \multicolumn{3}{|c|}{$\begin{array}{c}\text { Model } 3 \\
\text { SALES }\end{array}$} \\
\hline & Internet & $\begin{array}{c}\text { Non- } \\
\text { Internet }\end{array}$ & Diff $^{+}$ & Internet & $\begin{array}{c}\text { Non- } \\
\text { Internet }\end{array}$ & Diff $^{+}$ & Internet & $\begin{array}{c}\text { Non- } \\
\text { Internet }\end{array}$ & Diff $^{+}$ \\
\hline INTERCEPT & $\begin{array}{c}-23.04^{* * *} \\
(-1.7)\end{array}$ & $\begin{array}{c}-14.055^{* *} \\
(-2.24)\end{array}$ & & $\begin{array}{c}-18.498 \\
(-1.42)\end{array}$ & $\begin{array}{c}-12.954^{* *} \\
(-2.11)\end{array}$ & & $\begin{array}{c}-17.74 \\
(-1.4)\end{array}$ & $\begin{array}{c}-14.119^{* *} \\
(-2.35)\end{array}$ & \\
\hline POSEPS & $\begin{array}{l}-1.587 \\
(-0.15)\end{array}$ & $\begin{array}{l}1.936 \\
(1.02)\end{array}$ & 0.766 & & & & & & \\
\hline NEGEPS & $\begin{array}{l}-2.475 \\
(-1.07)\end{array}$ & $\begin{array}{l}-0.100 \\
(-0.10)\end{array}$ & 0.446 & & & & & & \\
\hline POSCFO & & & & $\begin{array}{l}3.431 \\
(0.75)\end{array}$ & $\begin{array}{l}0.539 \\
(0.98)\end{array}$ & 0.523 & & & \\
\hline NEGCFO & & & & $\begin{array}{l}-1.31 \\
(-0.4)\end{array}$ & $\begin{array}{c}0.56 \\
(0.33)\end{array}$ & 0.886 & & & \\
\hline SALESPS & & & & & & & $\begin{array}{l}0.028 \\
(0.04)\end{array}$ & $\begin{array}{c}0.095 \\
(1.54)\end{array}$ & 0.654 \\
\hline POSBV & $\begin{array}{l}4.543^{*} \\
(1.86)\end{array}$ & $\begin{array}{l}-0.021 \\
(-0.04)\end{array}$ & 0.064 & $\begin{array}{l}4.578^{*} \\
(1.86)\end{array}$ & $\begin{array}{c}0.06 \\
(0.13)\end{array}$ & 0.061 & $\begin{array}{l}4.383^{*} \\
(1.79)\end{array}$ & $\begin{array}{l}0.075 \\
(0.16)\end{array}$ & 0.071 \\
\hline NEGBV & $\begin{array}{l}-0.89 \\
(-0.45)\end{array}$ & $\begin{array}{l}-0.935 \\
(-1.06)\end{array}$ & 0.682 & $\begin{array}{l}-1.117 \\
(-0.55)\end{array}$ & $\begin{array}{l}-0.819 \\
(-0.94)\end{array}$ & 0.657 & $\begin{array}{l}-1.244 \\
(-0.63)\end{array}$ & $\begin{array}{l}-0.525 \\
(-0.59)\end{array}$ & 0.677 \\
\hline FLOAT & $\begin{array}{c}-56.49^{* * * *} \\
(-3.92)\end{array}$ & $\begin{array}{c}-12.76^{* * *} \\
(-2.68)\end{array}$ & $<0.01$ & $\begin{array}{c}-57.57^{* * *} \\
(-3.98)\end{array}$ & $\begin{array}{c}-13.66^{* * *} \\
(-2.84)\end{array}$ & $<0.01$ & $\begin{array}{c}-58.49^{* * *} \\
(-4.08)\end{array}$ & $\begin{array}{c}-14.22^{* * *} \\
(-2.98)\end{array}$ & $<0.01$ \\
\hline SGR & $\begin{array}{l}3.067^{*} \\
(1.84)\end{array}$ & $\begin{array}{c}2.425^{*} \\
(1.7)\end{array}$ & 0.032 & $\begin{array}{l}3.313^{* *} \\
(1.99)\end{array}$ & $\begin{array}{l}2.517^{*} \\
(1.79)\end{array}$ & 0.022 & $\begin{array}{l}3.275^{*} \\
(1.95)\end{array}$ & $\begin{array}{l}2.62^{*} \\
(1.88)\end{array}$ & 0.024 \\
\hline PARTIAL & $\begin{array}{c}49.029^{* * * *} \\
(4.21)\end{array}$ & $\begin{array}{l}29.78^{* * *} \\
(5.25)\end{array}$ & $<0.01$ & $\begin{array}{c}45.37^{* * *} \\
(3.95)\end{array}$ & $\begin{array}{c}29.23^{* * *} \\
(5.23)\end{array}$ & $<0.01$ & $\begin{array}{c}45.96^{* * *} \\
(4.05)\end{array}$ & $\begin{array}{c}30.13^{* * *} \\
(5.47)\end{array}$ & $<0.01$ \\
\hline POST98 & $\begin{array}{l}4.605^{*} \\
(1.76)\end{array}$ & $\begin{array}{l}2.972^{* *} \\
(2.06)\end{array}$ & 0.092 & $\begin{array}{l}4.72^{*} \\
(1.75)\end{array}$ & $\begin{array}{l}2.756 \\
(1.9)\end{array}$ & 0.098 & $\begin{array}{l}4.244^{*} \\
(1.76)\end{array}$ & $\begin{array}{l}2.915^{* *} \\
(2.05)\end{array}$ & 0.123 \\
\hline Adjusted $\mathrm{R}^{2}$ & $40.39 \%$ & $33.69 \%$ & & $39.92 \%$ & $33.86 \%$ & & $40.18 \%$ & $35.30 \%$ & \\
\hline
\end{tabular}

${ }^{+}$Difference between Internet and non-Internet firms using an $\mathrm{F}$ test (p-value reported).

**** Significant at the $1 \%$ level using a two-tailed test.

** Significant at the 5\% level using a two-tailed test.

* Significant at the $10 \%$ level using a two-tailed test.

\section{Definition of Variables}

$\begin{array}{ll}\text { POSEPS } & \text { EPS * Dummy for positive earnings } \\ \text { NEGEPS } & \text { EPS } * \text { (1-Dummy for positive earnings) } \\ \text { POSCFO } & \text { CFO per share * Dummy for positive cash flow } \\ \text { NEGCFO } & \text { CFO per share * (1- Dummy for positive cash flow) } \\ \text { SALESPS } & \text { Sales per share } \\ \text { POSBV } & \text { Book Value per share * Dummy for positive Book Value } \\ \text { NEGBV } & \text { Book Value per share * (1-Dummy for positive Book Value) } \\ \text { FLOAT } & \text { Percentage of shares outstanding offered in the IPO } \\ \text { SGR } & \text { Annual Sales Growth in the years prior to the IPO } \\ \text { PARTIAL } & \text { Offer price scaled by the midpoint of the offer range } \\ \text { POST98 } & \text { Dummy Variable for period after Dec } 31,1998\end{array}$


Table 8

Regressions with Time Period Interaction on Earnings

(t-statistics in parentheses, $\mathrm{n}=100$ )

\begin{tabular}{|c|c|c|c|c|c|c|}
\hline & \multicolumn{3}{|c|}{ Regression for IPOPRICE } & \multicolumn{3}{|c|}{ Regression for ENDPRICE } \\
\hline & Internet & $\begin{array}{c}\text { Non- } \\
\text { Internet }\end{array}$ & Diff $^{+}$ & Internet & $\begin{array}{c}\text { Non- } \\
\text { Internet }\end{array}$ & Diff $^{+}$ \\
\hline INTERCEPT & $\begin{array}{c}14.743^{* * *} \\
(10.42)\end{array}$ & $\begin{array}{c}12.037^{* * *} \\
(11.1)\end{array}$ & & $\begin{array}{c}-23.544^{*} \\
(-1.72)\end{array}$ & $\begin{array}{c}-12.557^{* *} \\
(-2.00)\end{array}$ & \\
\hline POSEPS & $\begin{array}{l}4.397 \\
(0.59)\end{array}$ & $\begin{array}{c}3.216^{* *} \\
(2.14)\end{array}$ & 0.120 & $\begin{array}{l}6.659 \\
(0.25)\end{array}$ & $\begin{array}{l}5.045^{* *} \\
(1.99)\end{array}$ & 0.484 \\
\hline POSEPS*POST 98 & $\begin{array}{l}-4.911 \\
(-0.61)\end{array}$ & $\begin{array}{l}-3.988^{*} \\
(-1.88)\end{array}$ & 0.130 & $\begin{array}{l}-9.693 \\
(-0.33)\end{array}$ & $\begin{array}{l}-6.444^{*} \\
(-1.81)\end{array}$ & 0.573 \\
\hline NEGEPS & $\begin{array}{c}-0.34 \\
(-0.56)\end{array}$ & $\begin{array}{l}-0.302 \\
(-0.48)\end{array}$ & 0.517 & $\begin{array}{l}-2.611 \\
(-1.1)\end{array}$ & $\begin{array}{l}-0.092 \\
(-0.09)\end{array}$ & 0.437 \\
\hline POSBV & $\begin{array}{c}0.44 \\
(0.64)\end{array}$ & $\begin{array}{l}0.321 \\
(1.02)\end{array}$ & 0.273 & $\begin{array}{l}4.576^{*} \\
(1.86)\end{array}$ & $\begin{array}{l}0.238 \\
(0.47)\end{array}$ & 0.063 \\
\hline NEGBV & $\begin{array}{l}-0.302 \\
(-0.55)\end{array}$ & $\begin{array}{l}-1.03 \\
(-1.51)\end{array}$ & 0.191 & $\begin{array}{l}-0.918 \\
(-0.46)\end{array}$ & $\begin{array}{l}-1.012 \\
(-1.16)\end{array}$ & 0.654 \\
\hline FLOAT & $\begin{array}{c}-16.74^{* * *} \\
(-4.22)\end{array}$ & $\begin{array}{c}-7.319^{* * *} \\
(-2.57)\end{array}$ & $<0.01$ & $\begin{array}{c}-56.95^{* * *} \\
(-3.91)\end{array}$ & $\begin{array}{c}-13.74^{* * *} \\
(-2.9)\end{array}$ & $<0.01$ \\
\hline SGR & $\begin{array}{l}0.873^{*} \\
(1.93)\end{array}$ & $\begin{array}{l}0.792 \\
(0.91)\end{array}$ & 0.044 & $\begin{array}{c}3.08^{*} \\
(1.84)\end{array}$ & $\begin{array}{c}2.28 \\
(1.61)\end{array}$ & 0.037 \\
\hline PARTIAL & & & & $\begin{array}{c}49.29^{* * *} \\
(4.2)\end{array}$ & $\begin{array}{c}27.95^{* * *} \\
(4.91)\end{array}$ & $<0.01$ \\
\hline POST98 & $\begin{array}{c}2.422^{* * * *} \\
(2.66)\end{array}$ & $\begin{array}{l}1.934^{*} \\
(1.98)\end{array}$ & 0.032 & $\begin{array}{l}4.856^{*} \\
(1.79)\end{array}$ & $\begin{array}{c}4.228^{* * * *} \\
(2.67)\end{array}$ & 0.057 \\
\hline Adjusted $\mathrm{R}^{2}$ & $24.41 \%$ & $10.48 \%$ & & $39.80 \%$ & $35.31 \%$ & \\
\hline
\end{tabular}

${ }^{+}$Difference between Internet and non-Internet firms using a F test (p-value reported)

${ }^{* * *}$ Significant at the $1 \%$ level using a two-tailed test.

** Significant at the 5\% level using a two-tailed test.

* Significant at the $10 \%$ level using a two-tailed test.

\section{Definition of Variables}

POSEPS $\quad$ EPS * Dummy for positive earnings

NEGEPS $\quad$ EPS * (1-Dummy for positive earnings)

POSBV Book Value per share* Dummy for positive Book Value

NEGBV Book Value per share * (1-Dummy for positive Book Value)

FLOAT Percentage of shares outstanding offered in the IPO

SGR Annual Sales Growth in the years prior to the IPO

PARTIAL Offer price scaled by the midpoint of the offer range

POST98 Dummy Variable for period after Dec 31, 1998 
Table 9

Comparison of Early (1996-1998) and Late (1999) IPOs

\begin{tabular}{|l|c|c|c|c|c|c|}
\multicolumn{4}{c}{ Internet Firms } \\
\hline Variable & $\begin{array}{c}\text { Early } \\
(\mathrm{n}=54)\end{array}$ & $\begin{array}{c}\text { Late } \\
(\mathrm{n}=46)\end{array}$ & $\begin{array}{c}\text { T Stat for } \\
\text { Difference }\end{array}$ & $\begin{array}{c}\text { Early } \\
(\mathrm{n}=54)\end{array}$ & $\begin{array}{c}\text { Late } \\
(\mathrm{n}=46)\end{array}$ & $\begin{array}{c}\text { T Stat } \\
\text { Difference }\end{array}$ \\
\hline IPOPRICE & 11.88 & 14.88 & $3.38^{* * *}$ & 11.27 & 12.75 & $1.72^{*}$ \\
ENDPRICE & 18.56 & 30.87 & $3.45^{* * *}$ & 13.25 & 16.55 & $1.98^{* *}$ \\
EPS & -0.76 & -0.57 & 1.28 & -0.19 & -0.02 & 0.93 \\
CFOPS & -0.43 & -0.39 & 0.30 & 0.14 & 0.82 & $2.20^{* *}$ \\
SALESPS & 1.48 & 1.01 & -1.24 & 5.49 & 8.79 & 1.36 \\
BVPS & 0.23 & -0.39 & $-2.71^{* * *}$ & 0.12 & 0.71 & 1.38 \\
FLOAT & $24.9 \%$ & $22.0 \%$ & -1.37 & $29.2 \%$ & $32.5 \%$ & 0.98 \\
SGR & $78.9 \%$ & $101.5 \%$ & 1.24 & $34.7 \%$ & $39.2 \%$ & 0.45 \\
PARTIAL & 1.02 & 1.13 & $3.94^{* * *}$ & 1.000 & 1.000 & 0.01 \\
\hline
\end{tabular}

${ }^{* * * *}$ Significant at the $1 \%$ level using a two-tailed test.

** Significant at the 5\% level using a two-tailed test.

* Significant at the $10 \%$ level using a two-tailed test.

\section{Definition of Variables}

$\begin{array}{ll}\text { IPOPRICE } & \text { IPO Price } \\ \text { ENDPRICE } & \text { Price at the end of first trading day } \\ \text { EPS } & \text { Earnings per Share } \\ \text { CFOPS } & \text { Cash From Operations per share } \\ \text { SALESPS } & \text { Sales per share } \\ \text { BVPS } & \text { Book Value per share } \\ \text { FLOAT } & \text { Percentage of shares outstanding offered in the IPO } \\ \text { SGR } & \text { Annual Sales Growth in the years prior to the IPO } \\ \text { PARTIAL } & \text { Offer price scaled by the midpoint of the offer range }\end{array}$

